\title{
COMPARING THE PERCEPTIONS OF INDONESIANS AND MALAYSIANS TOWARD THE CHINA'S BELT AND ROAD INITIATIVE: FACTS AND TRENDS
}

\author{
Yasmi Adriansyah ${ }^{1}$, Yin Shi Wu ${ }^{2}$ \\ Al-Azhar University of Indonesia
}

\begin{abstract}
:
This article examines public perceptions in Indonesia and Malaysia regarding the China's Belt and Road Initiative (BRI). In order to get a comprehensive picture of the subject matter, the article applies three perspectives, namely International Politics, Economy and Debt Trap, and Public Acceptance. The attachments of Indonesia (under Joko Widodo administration) and Malaysia (under Najib Razak administration) are analyzed, mainly by observing the perceptions of the political elites and opinion polls in these most populous Muslim countries. The findings show that both governments in the two countries had exhibited high inclination toward the BRI. Interestingly, their public show different attitudes and many people are against or at least critical of these policies. It therefore suggests that the pro-BRI policies of the governemnts must be managed with high care in order to balance the different interrests with the popular interests.
\end{abstract}

Keywords: Belt and Road, debt traps, foreign policy, China, Indonesia, Malaysia.

Título en Castellano: Comparación de las percepciones en Indonesia y Malasia sobre la Iniciativa china "Una Franja, Una Ruta": Hechos y Tendencias

\section{Resumen:}

Este artículo examina las percepciones públicas en Indonesia y Malasia hacia la Iniciativa china "Una Franja Una Ruta" (BRI). Con el fin de obtener una imagen completa en el análisis de este asunto, el artículo aplica tres perspectivas, a saber, la política internacional, la economía y la trampa de la deuda, y la aceptación pública. Las adhesions realizadas por Indonesia (bajo la administración Joko Widodo) y Malasia (bajo la administración Najib Razak) son analizadas, principalmente observando las percepciones de las élites políticas y las encuestas de opinión en estos países musulmanes más poblados. Los resultados muestran que ambos gobiernos mostraron una alta inclinación hacia la BRI. Curiosamente, su público muestra diferentes actitudes. Muchos están en contra o al menos se muestran críticos con esta política. Por lo tanto, esto sugiere que las políticas gubernamentales pro-BRI deben ser gestionadas con sumo cuidado para equilibrarlas con los intereses del público.

Palabras Clave: "Una Franja, Una Ruta”, trampa de la deuda, política exterior, China, Indonesia, Malasia.

Copyright @ UNISCI, 2019.

Las opiniones expresadas en estos artículos son propias de sus autores, y no reflejan necesariamente la opinión de UNISCI. The views expressed in these articles are those of the authors, and do not necessarily reflect the views of UNISCI.

\footnotetext{
${ }^{1}$ Yasmi Adriansyah, is Lecturer and Researcher at the University of Al Azhar Indonesia (UAI), Jakarta. The initial writing of this paper received supports from the Center for Research and Community Development (LP2M) of UAI.

E-mail: <yasmi.adriansyah@uai.ac.id>

${ }^{2}$ Dr. Yin Shi Wu is part-time Lecturer at the University of Al Azhar Indonesia (UAI), Jakarta

E-mail: <adolfo0314@gmail.com>

DOI: http://dx.doi.org/10.31439/UNISCI-83
} 


\section{Introduction}

The policies of the government of the People's Republic of China (PRC) ${ }^{3}$ for developing the Belt and Road Initiative (BRI) have triggered remarkable discussions and debates among intellectuals, policy makers and business communities.

The discussions and debates not only have emerged in the western world, most of them considering the Chinese initiative, as the initiative of a communist country and part of its expansionist strategy. As a matter of interest, negative sentiments toward the BRI have also emerged in Southeast Asia, including in Indonesia and Malaysia, the major Muslim countries.in the region.

As a brief introduction, we can say that the initiative and policies for the implementation of the Belt and Road Initiative - formerly known as One Belt One Road (OBOR) - ${ }^{4}$ are a global development strategy adopted by the Chinese government in 2013. Through this initiative, China aims to increase connectivity with countries in Asia, Africa and Europe especially in the areas of trade, investment and infrastructure development. Through the BRI, Xi Jinping is eager to build the infrastructure that connects China with the surrounding region and its less developed neighbors. This policy can be regarded as one of the greatest development plans in the history of the modern world.

From the context of geographical interconnection between countries, the BRI is divided into two:

- The Silk Road Economic Belt (herein referred as 'Economic Belt') and

- The 21st Century Maritime Silk Road (herein referred as 'Maritime Silk Road').

If the Economic Belt connects China westward across countries such as Turkmenistan and Turkey, crossing some Balkan countries and Ukraine before passing to Moscow and arriving to Rotterdam (Europe), the Maritime Silk Road tries to further strengthening China's connectivity with Southeast Asia, South Asia, Africa, Middle East, Greece and Italy concluding in the Economic Belt (Europe). In other words, the BRI is an interconnected link between China and the regions that separate China from Europe (See Figure 1). ${ }^{5}$

\footnotetext{
${ }^{3}$ This abbreviation will be used interchangeably with the word 'China'.

${ }^{4}$ China's Communist Party formally adopted the BRI in 2017 during the $19^{\text {th }}$ National Party Congress with a resolution to achieve "shared growth through discussion and collaboration". See Hurley, John; Morris, Scott and Portelance, Gailyn (2018): "Examining the Debt Implication of the Belt and Road Initiative from a Policy Perspective" in CGD Policy Paper 121. Washington, Center for Global Development, p. 1.

${ }^{5}$ There are 68 countries that fall under the scope of BRI. By region, the countries are:

- East and Southeast Asia (14): Brunei, China, Indonesia, Malaysia, Mongolia, Myanmar, Cambodia, Laos, the Philippines, Singapore, South Korea, Thailand, Timor Leste, and Vietnam;

- Central and South Asia (13): Afghanistan, Bangladesh, Bhutan, India, Kazakhtan, Kyrgyztan, Maldives, Nepal, Pakistan, Sri Lanka, Tajikistan, Turkmenistan, and Uzbekistan;

- Middle East and Africa (17): Bahrain, Djibouti, Egypt, Ethiopia, Iran, Iraq, Israel, Jordan, Kenya, Kuwait, Lebanon, Oman, Qatar, Saudi Arabia, Syria, United Arab Emirates, and Yemen;

- Europe and Euraisia (24): Albania, Armenia, Azerbaijan, Belarus, Bosnia and Herzegovina, Bulgaria, Croatia, Czech Republic, Estonia, Hungary, Latvia, Lithuania, Macedonia, Moldova, Montenegro, Poland, Romania, Russia, Serbia, Slovakia, Slovenia, Turkey, and Ukraine.
}

See Hurley et al, op. cit., pp. 6-7. 
Figure 1: Countries along the Belt and Road Initiative

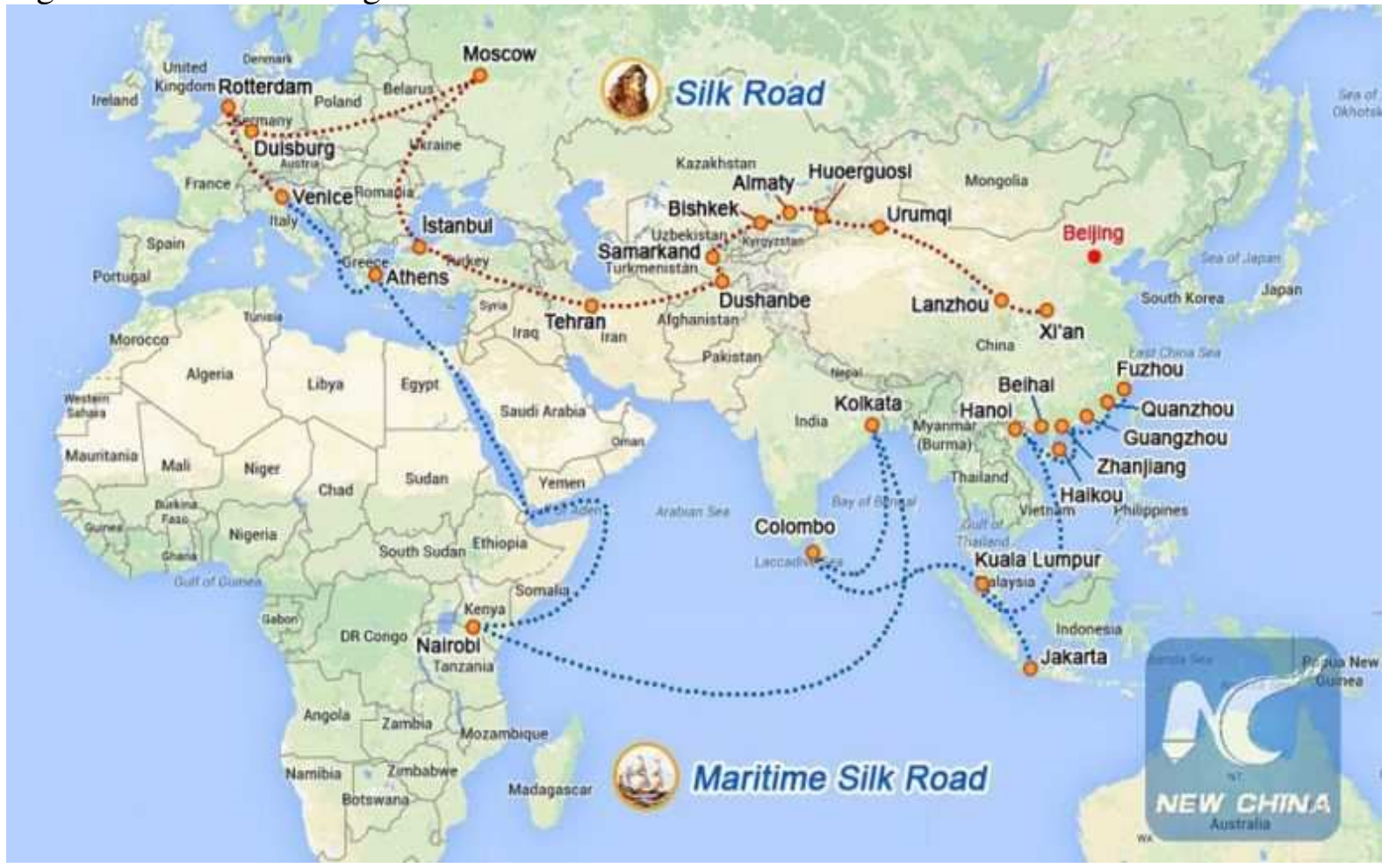

Source: (https://www.chinadailyhk.com/articles/165/106/34/1545891548672.html)

As a consequence, the Belt and Road Initiative shall force China to negotiate with the countries linked to the Belt and Road projects, especially when planning and implementing agreed measures in the context of achieving results in its ambitious goals. As for the negotiation developed, there is a take-and-give situation. China as the initiator, on one hand, must be able to convince other countries that their participation will meet their interests. On the other hand, in reciprocity, China will demand that these countries meet the requests of the world's most populous country.

Challenges and even problems have been arising in the stages of negotiation, implementation, and the various dynamics surrounding them. China's propaganda has indeed given various positive images of the BRI potential, such as increased trade, more productivity through, among others, human movement and faster economic growth. For countries less developed or in need of development funds, the BRI may have been interpreted as an instant panacea and therefore turns as an attractive policy option.

However, problems have arisen when there is a connection between the profit expectations of the countries involved and the demands of the PRC. Negotiations and bilateral relations between China and those countries can be positive or mutually beneficial. On the other hand, this may move to a conflict situation. As is commonly known in the world of diplomacy, nothing is free ("there is no free lunch"), conflicts will arise when the above intersections are not carefully managed. There is a consistent blame in many countries accusing China for its economic approaches and policies and labeling them as parasitic: they sell Chinese products or contruct infrastructure using Chinese traders, shops, goods and Chinese labor and putting the profits in Chinese Banks or using alternative channels. To this, the thorny issue of the debt trap has to be added.

This article attempts to compare and analyze the views emerging in Indonesia and Malaysia regarding the BRI. Prior to discussing them, the article will briefly discuss a number 
of BRI's challenges, particularly from the perspective of international politics, economy and public acceptance.

\section{BRI and International Politics}

In the field of international politics, we argue that there are always criticisms from the United States (US) and its close allies against the BRI because in a natural sense they will never want to see an increase in the domination of China in the region. The US and its allies will always see the BRI as part of a grand strategy and efforts of China to dominate the region and even the world, the so-called 'struggle for power'. China has often been referred as a 'dragon' due to the size of its country. The more expansive policies are implemented by China, more cautious other governments consequently become.

Some may view the BRI as merely a part of China's economic interests in the region (geo-economic interest). If we observe from the projects being run or developed, this view has some consistency as most of the projects are economic in nature, particularly in the development of energy resources, tourism, or transportation. Some of the projects are, among others, Central Asia-China Gas Pipeline (energy, in multiple countries), MNC Lido City (tourism, Indonesia), and Europe-China Rail Link I \& II (transport, multiple countries). ${ }^{6}$

Adding to this, most of the funding institutions are also economic in nature. The institutions created are, inter alia, the Asian Infrastructure Investment Bank (AIIB), the Asian Development Bank (ADB), Export-Import Bank of China (CHEXIM), Industrial and Commercial Bank of China (ICBC), and China Investment Corporation (CIC). ${ }^{7}$

Nonetheless, there is also a view that the BRI is part of the Chinese strategic-political interests (geostrategic interest). ${ }^{8}$ One example is the development program for the ChinaPakistan Economic Corridor (CPEC). The program is often regarded as part of the major projects of the BRI connecting Kashgar in China's Xinjiang Province with the Gwadar Port in Baluchistan Province, Pakistan.

The reason for the geostrategic importance of the CPEC program is due to the proximity between the Port of Gwadar and the Persian Gulf. This proximity can be used by China to avoid the conventional path of the Malacca Strait, especially in the context of the supply of Chinese energy. Furthermore, the Port of Gwadar has also been used as part of the activities of the Navy of the People's Liberation Army. Some of their activities, are anti-piracy missions in the Arabian Sea and the evacuation of Chinese workers in Libya but now are increasing their reach, including the Horn of Africa, the Red Sea and reaching the Mediterranean.

In the perspective of international politics, the strengthening of China's domination in the region is also of particular concern when it is associated with China's territorial disputes with Asian countries. In a 2013 survey by the Pew Research Center, as noted by Shambaugh, the majority of the population in the Philippines (90\%), Japan (82\%), South Korea (77\%) and Indonesia (62\%) stated that the territorial disputes with China are a major problem for their countries. ${ }^{9}$ Similarly, the majority of citizens in Japan, South Korea, and the Philippines also stated that that the expansion of China's military capability is a negative thing for their countries.

The recent trends in terms of international opinions toward China do not differ much either. The Pew Research Center recently reveals that the percentage of unfavorable-favorable sentiments among the people in the above-mentioned countries are as follows: the Philippines

\footnotetext{
${ }^{6}$ For the more comprehensive data on the BRI projects, see https://www.beltroad-initiative.com/projects/.

${ }^{7}$ See the section of Funding of the Initiative at https://www.beltroad-initiative.com/belt-and-road/.

${ }^{8}$ Cai, op cit., pp. $4-5$.

${ }^{9}$ Shambaugh, David (2014): China at the Crossroads: Ten Major Reform Challenges. Washington DC, The Brookings Institution, p. 16.
} 
(54\% unfavorable - 42\% favorable), Japan (85-14), South Korea (63-34), and Indonesia (3636). ${ }^{10}$ In other words, most countries in the region still have unfavorable sentiments toward China.

\section{Economy: Between Opportunities and Debt Traps}

On the question of debt and its relations with the BRI, the pioneering study is the one conducted by Hurley et al. ${ }^{11}$ This study argues that out of the 68 countries involved at the BRI, eight of them are at particular risk of debt distress. These eight countries are Djibouti, Maldives, Laos, Montenegro, Mongolia, Tajikistan, Kyrgizstan, and Pakistan. These countries face debt-toGDP ratios beyond 50 percent, of which 40 percent or more of their external debts are owed to China and more particularly that fall under the BRI.

One of the problems of BRI is the concerns on how the funds are being managed. In general, the main BRI funds are loans, not grants. To make the things more complicated, the funds are often lent with commercial interest rates, potentially leaving the borrowing countries with unsustainable debt. ${ }^{12}$ One example of this potential problem of unsustainable debt is the high-speed rail line in Laos. This project costs half of the Laos GDP, leaving this poor Southeast Asia country at a high risk of debt trap. Another example is Pakistan, where, due to its deteriorating finances, given the numerous BRI projects, it was forced to seek a bailout from the International Monetary Fund (IMF) amounted to US\$ 6 billion. ${ }^{13}$

The existence of BRI might have raised questions from countries involved whether their involvement will generate benefits or just the opposite. China will indeed invest a huge amount in infrastructure. This however does not rule out the possibility that other countries perceive the policy merely as something that satisfies the interests of China through its infrastructure connectivity rather than the interests of the other countries involved.

Cai, for example, views that the BRI as heavily linked to the interests of China, particularly in the context of industrial upgrading. ${ }^{14}$ In the past three decades China has an impressive reputation as a 'world's factory' especially with its comparative advantage of low labor costs. But along with the disappearance of this advantage, leaders in China want to get higher market targets from the global trade value chain. In order to realize this, China has to improve its industry, which implies to be more innovation-driven, to emphasize quality more than quantity, restructuring the low-cost manufacturing industry.

Another criticism of the BRI is the negative impact on economic relations. Some scholars have warned that countries that are economically under the influence of China may fall into the so-called 'debt trap'. Sri Lanka and Pakistan are the two contemporary examples of China's debt traps. Cruz, for example, writes as follows:

China is investing billions of dollars in infrastructure and development in Sri Lanka but may local citizens feel the country is being sold to the Chinese....Hambantota was built by a Chinese company and funded by Chinese loans. But now Sri Lanka is

\footnotetext{
${ }^{10}$ Silver, Laura; Devlin, Kat and Huang, Christine: "China's Economic Growth Mostly Welcomed in Emerging Markets, but Neighbors Wary of Its Influence", Pew Research Center, 5 December 2019, at https://www.pewresearch.org/global/2019/12/05/attitudes-toward-china-2019/

${ }^{11}$ Hurley et al, op. cit.

${ }^{12}$ Gerstel, Dylan: "It's a (Debt) Trap! Managing China-IMF Cooperation Across the Belt and Road", New Perspestives in Foreign Policy, Issue 16, Center for Strategic \& International Studies ,17 October 2018.

${ }^{13}$ Bennon, Michael (2019): "Bailing Out China's Belt and Road", Center for Strategic and International Studies.

${ }^{14}$ Cai, op cit.
} 
struggling to repay that money and so has signed an agreement to give a Chinese firm a stake in the port as a way of paying down some of that debt. ${ }^{15}$

Based on the article quotated above, it can be said that some Sri Lankans feel that their country has been sold because of China's debt trap. China indeed seems to be providing billions of dollars in building infrastructure in Sri Lanka. But when Sri Lanka struggled to pay its debts, the country was finally forced to give up some of its authority transferred to China, in this case related to the management of the airport and port strategic assets.

Furthermore, the existence of debt traps is sometimes considered as part of China'sdiplomacy. As argued by Chellaney,

If there is one thing China's leaders excel, it is the use of economic tools to advance their country's geostrategic interests. Through its \$1 trillion "one belt, one road" initiative", China is supporting infrastructure projects in strategically located developing countries often by extending huge loans to their governments. As a result, countries are becoming ensnared in a debt trap that leaves them vulnerable to China's influence. ${ }^{16}$

Based on the above explanation, it is clear that the China's loans to other countries, especially in the context of BRI, are strongly nuanced as 'debt trap diplomacy'. For fragile economies, they are more likely to fall into the debt trap. In the long run this can have socio-political impacts.

What are the Chinese responses to the mostly negative sentiments described above? While there have been no specific counters from the government of China concerning debt trap, scholars note that the country has attempted to increase the transparency of BRI. ${ }^{17}$ By doing so, the government expects that international community will have more understanding on China's stances. Further, China is eager to demonstrate that it will not force other countries to sign BRI projects and will only collaborate with willing partners.

\section{Public Acceptance}

In the context of public acceptance, there are concerns that the BRI will bring more penetration of Chinese values, including communism, to the countries involved. These concerns, if not carefully managed, will degrade their attachment and may turn around, being counterproductive for the countries involved in BRI.

Indeed, a few years ago in a number of countries the international image of China was quite positive. These countries were, according to Shambaugh (2014: 10), those included in the 'pockets of favorability'. They are, among others, Pakistan, Malaysia, Indonesia, Kenya, Senegal, Nigeria, and Venezuela. ${ }^{18}$

On the other hand, the Pew Global Attitudes 2013-14 survey found that China's international image is somewhat mixed. ${ }^{19}$ Even if divided per region and compared with the United States, China only received a higher favorability rating in the Middle East. The comparison of the favorability between the US and China in Africa was 74\% - 70\%, in Asia 66\% - 61\%, Europe 66\% - 39\%, Latin America 66\% - 48\%, and the Middle East 30\% - 49\%.

\footnotetext{
${ }^{15}$ Cruz, Elfren S.: “China Debt Trap”, The Philippine Star, 3 August 2017.

${ }^{16}$ Chellaney, Brahma (2017):” China's Debt-Trap Diplomacy”, in Project Syndicate.

${ }^{17}$ Haenle, Paul; Trenin, Dmitri; Baguev, Alexander; Valasek, Tomas; Baruah, Dashana M.; Yujun, Feng and Bin, Ma: "How are various Countries Responding to China's Belt and Road Initiative?", Carnegie-Tsinghua Center for Global Policy, 25 April 2019.

${ }^{18}$ Shambaugh, op. cit., p. 10.

${ }^{19}$ Ibid, pp. 10-12.
} 
On the international opinions on China, the most recent survey conducted by the Pew Research Center demonstrates that China generally receives more unfavorable sentiments in the US, Europe and Asia, and more favorable sentiments in Russia, Ukraine, Middle East, Africa, and Latin America. ${ }^{20}$ According to scholars, China receives positive images in emerging markets though, at the same time, there have been disconfort with its rising stature. ${ }^{21} \mathrm{We}$ will observe closely this matter by comparing the facts and trends in Indonesia and Malaysia.

\subsection{Indonesian Perspective}

Indonesia has been viewed an important country by China, either in the context of bilateral relations or more specifically with regard to the BRI. As Damuri et al argue, "The BRI might be perceived as China's initiative to reactivate the historic Silk Road as the major route of China's trading activities with its neighboring countries ...; and Indonesia has a very strategic position in this maritime connectivity." 22

Since the launching of OBOR in 2013 and onwards, Indonesia has taken part in several projects, among others: Jakarta-Bandung high-speed rail, Manado-Bitung toll road, South Sumatera-5 power plant, and Morowali Industrial Park (see Figure 2 below). ${ }^{23}$ The JakartaBandung high-speed rail project was launched in 2016 with a main purpose to further connect Jakarta and Bandung with the planned $142 \mathrm{~km}$ railway. The Morowali Industrial Park project is an integrated industrial estate worth US\$ 8 billion investment, mainly dedicated for the production of nickel smelters, stainless steel, and carbon steel.

Figure 2: Key Belt and Road Projects in Indonesia (March 2018)

Name Status Cost (billions of \$)

Jakarta-Bandung high-speed rail Preparatory Phase 6.00 Wanado-Bitung toll road Under construction 0.37 Sumsel-5 power plan Completed
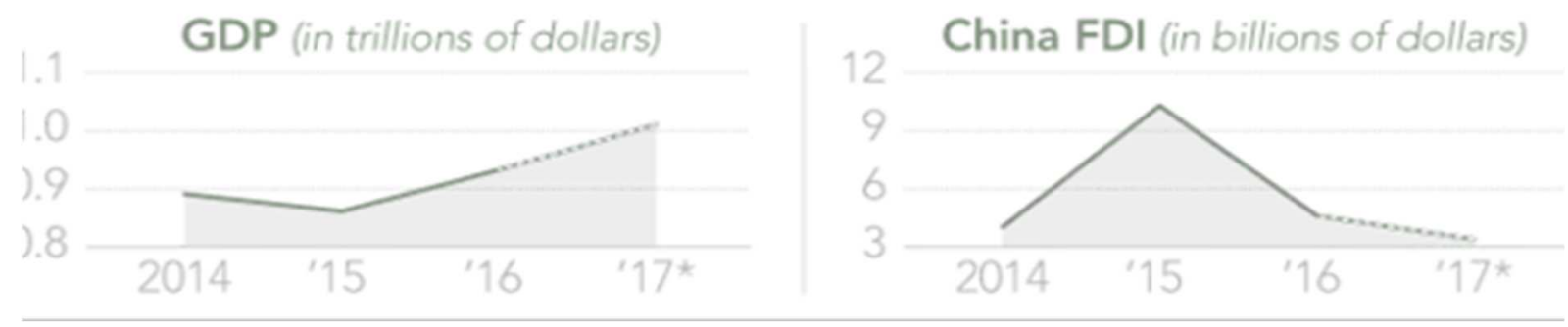

Source: Is China's Belt and Road working? A progress report from eight countries: https://asia.nikkei.com/Spotlight/Cover-Story/Is-China-s-Belt-and-Road-working-A-progress-report-from-eightcountries

In terms of bilateral cooperation under the BRI, Indonesia and China have signed the following agreements: MoU on Promoting Cooperation on the Development of Regional Comprehensive Economic Corridors (7 May 2018), MoU on Establishing a Joint Steering Committee for the Development of Regional Comprehensive Economic Corridors (23 October 2018), and MoU

\footnotetext{
${ }^{20}$ See Silver Laura, Devlin Kat and Suang Christine : China's Economic Growth Mostly Welcomed in Emerging Markets, but Neighbors Wary of Its Influence ", "Attitudes toward China", Pew Research Center, 5 December 2019, at https://www.pewresearch.org/global/2019/12/05/attitudes-toward-china-2019/

${ }^{21}$ Ibid.

${ }^{22}$ Damuri, Yose Rizal; Perkasa, Vidhyandika; Atje, Raymond and Hirawan, Fajar (2019): Perceptions and Readiness of Indonesia towards the Belt and Road Initiative: Understanding Local Perspectives, Capacity, and Governance. Jakarta, Center for Strategic and International Studies, p. 9.

${ }^{23}$ See also Yamada, Go (2018): "Is China's Belt and Road Working? A Progresss Report from Eight Countries", in Nikkei Asian Review, 28 March 2018.
} 
on Jointly Promoting Cooperation within the Framework on GMF and the Silk Road Economic Belt and $21^{\text {st }}$ Century Maritime Silk Road Initiative (23 October 2018). ${ }^{24}$

Further projects and studies have been underway under the Cooperation Plan on Regional Comprehensive Economic Corridors since its signature on 25 April 2019. There are also other 30 proposed projects under the plan. These projects and studies can be observed at Figure 3 and 4 respectively.

Figure 3: Project \& Studies in the Cooperation Plan on Regional Comprehensive Economic Corridors. Signed on April $25^{\text {th }}, 2019$

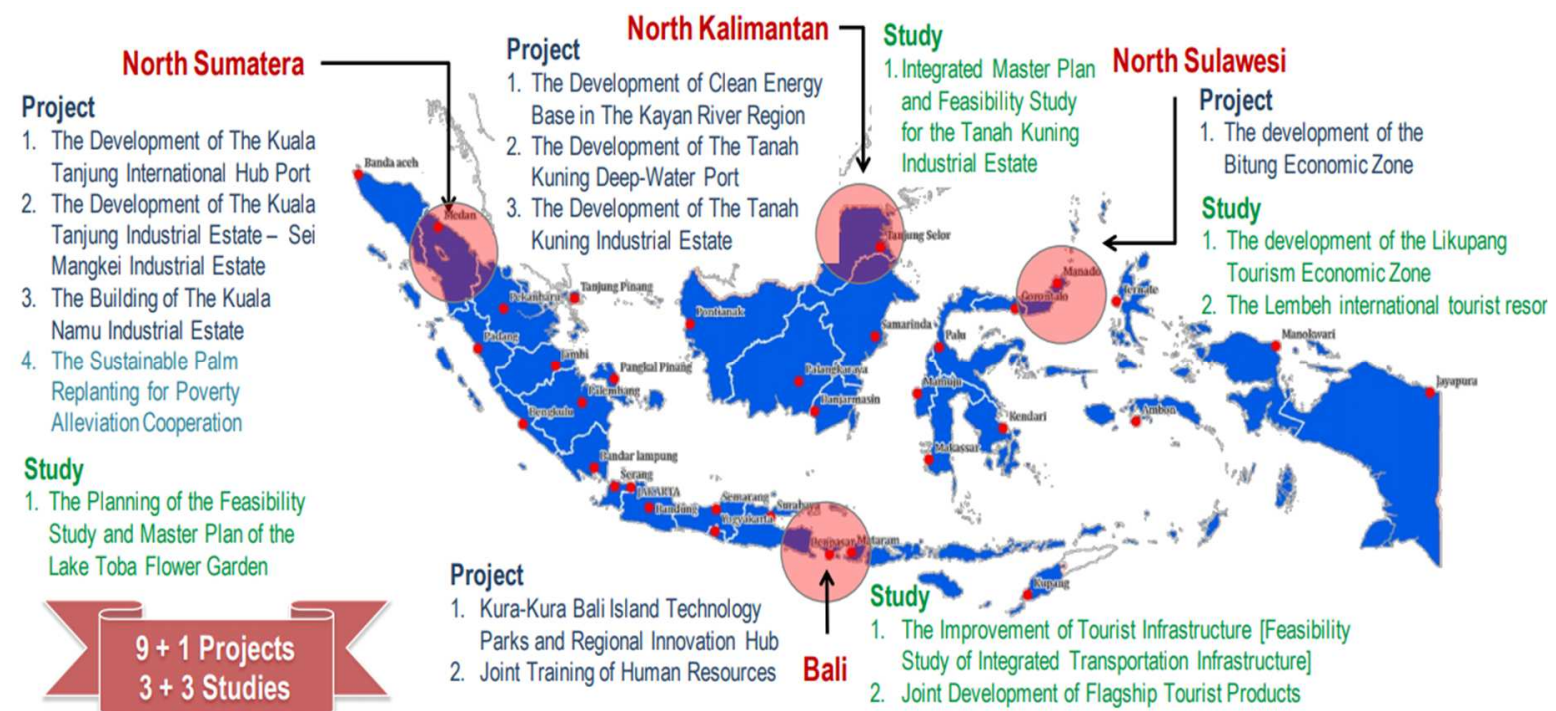

Source: Republic of Indonesia, Ministry of Maritime Affairs. 2019. https://maritim.go.id/synergy-great-nationschinas-belt-road-initiative-indonesias/

Figure 4: Proposed 30 Projects for Regional Comprehensive Economic Development Corridors

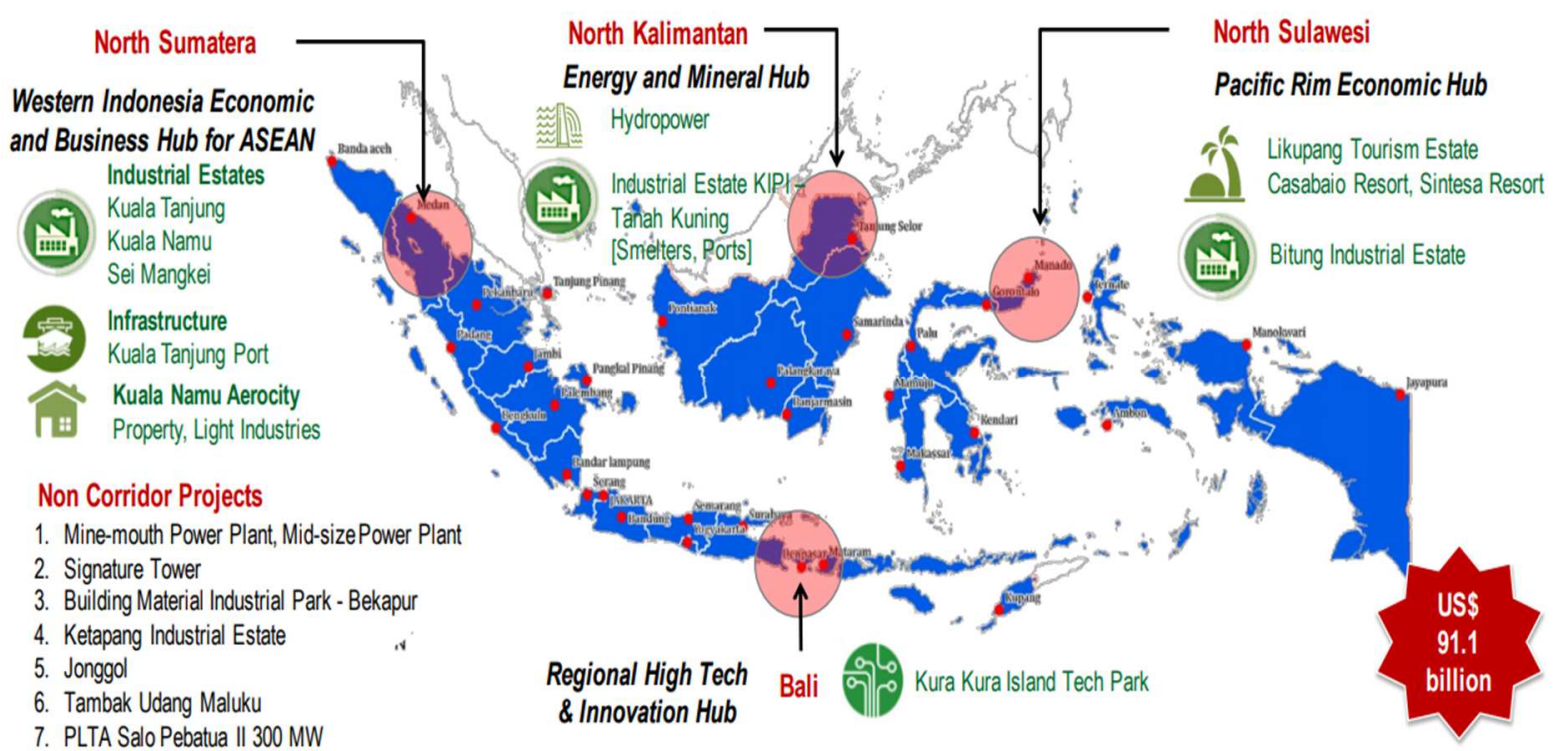

Source: Republic of Indonesia, Ministry of Maritime Affairs. 2019. https://maritim.go.id/synergy-great-nationschinas-belt-road-initiative-indonesias/

\footnotetext{
${ }^{24}$ Coordinating Ministry of Maritime Affairs (2019): “A Synergy between Two Great Nations: China's Belt \& Road Initiative and Indonesia’s Global Maritime Fulcrum”, Republic of Indonesia.
} 
In terms of how the government of Indonesia (under the Joko Widodo administration) looks at China and its BRI, the statement from the Coordinating Minister of Maritime Affairs, Luhut Panjaitan, is worth mentioning. In a signing ceremony event between Indonesia and China in 2018, Panjaitan stated (in an unofficial translation), "We have to be smart because all countries are looking for opportunities. What remains left are our intelligence in looking for them so that we can gain more profits. The advancement of China must be viewed as an opportunity to advance Indonesia." 25

Unquestionably the views from the Coordinating Ministry of Maritime Affairs are and will always be supportive. This is due to the fact that its task and function is to be the governmental coordinator representing Indonesia on the Belt and Road cooperation. Yet the views emerging from Indonesian public toward the BRI are somewhat mixed, even though most of them actually tend to be negative. If there are positive sentiments, they are due to the government's bold decision to embrace the BRI. Indonesia's President Joko Widodo stated the Indonesia's role in the ancient Silk Road trading route and urged other countries in the region to join and play a part in China's new Belt and Road Initiative. ${ }^{26}$

It is yet to be clear whether the government's decision to enter the BRI has been consulted with the Indonesian public. Popular consultations on the perception of Indonesians toward other countries may bring to a provisional conclusion that the public perceive China as a threat and, consequently, it can be argued that they do not wish to see more and deeper engagement with China. The survey carried out by the Media of the National Survey (Median) in September 2017 confirms this conclusion. Through the question, "In your opinion, which country in the world poses the greatest threat to Indonesia", the Median survey found that the highest percentage $\left(22.7 \%\right.$ ) responded that it is China, while the US received $14.1 \% .{ }^{27}$ In other words, with the strengthening of the Chinese hegemonic presence in Indonesia, has increasingly emerged concerns in the public about this phenomenon.

In a much earlier survey, the Jakarta-based Center for Strategic and International Studies (CSIS) further confirms the sentiment. Carrying out a survey in August 2017 particularly in the millennial generation (17 to 29 years old), the CSIS found out that $32.8 \%$ of the generation sees that cooperating with China creates disadvantages to Indonesia and only $11.7 \%$ believes that it will be otherwise. ${ }^{28}$

Interestingly, the survey shows that China receives the highest percentage when asking which is the country that has created more drawbaks to Indonesia. The second highest is the United States (29.9\% disadvantage vs $14.3 \%$ advantage). As for other countries, most of them receive a relatively balanced percentage in the perceptions or even a highly advantageous percentage (such as toward Saudi Arabia and ASEAN countries).

\subsection{Malaysian Perspective}

As the year 2017 marked the official adoption of Belt and Road Initiative by the People's Republic of China, one of the countries that gave strong support to the Initiative was Malaysia, particularly under the administration of former Prime Minister Najib Abdul Razak. Through an opinion article entitled "Why Malaysia supports China's Belt and Road", Najib stated:

\footnotetext{
${ }^{25}$ Coordinating Ministry of Maritime Affairs (2018): "Beberapa Kerja Sama Indonesia-Tiongkok itandatangani, Menko Luhut: Kami Tidak Ingin Hanya Bicara”, Republic of Indonesia

${ }^{26}$ Sheany: "Jokowi Optimistice about China's Belt and Road Initiative", Jakarta Globe, 16 May 2017.

${ }^{27}$ Aco, Hasanudin: "Survei Median: China Dianggap Sebagai Ancaman Terbesar Bagi Indonesia", Tribunnews, 16 November 2017.

28 "Ada Apa dengan Milenial? Orientasi Sosial, Ekonomi, dan Politik", Center for Strategic and International Studies, 2017.
} 
I am proud to be among the many heads of government and state and other world leaders gathering in Beijing for the Silk Road's present-day successor - President Xi's visionary "One Belt, One Road" initiative. The Belt and Road Forum for International Cooperation has an emphasis on mutual discussion, mutual construction and mutual sharing. This is greatly welcomed, and I am confident that the agreements many of the participants, including Malaysia, will be signing will set us on a strong footing for the next phase of this remarkable plan. ${ }^{29}$

As for China, it certainly welcomed the highly positive gesture shown by the then PM Najib. President Xi Jinping was reported to laud Malaysia as an early supporter of BRI and promised that Malaysia would gain the most from the Initiative.

The strong support from Malaysia is apparently due to the intention to further strengthen the country's bilateral relations with China. "Mr Xi said the China-Malaysia relationship is currently at its best ever and China will advance the comprehensive strategic partnership with Malaysia to further improve bilateral ties." 30

In fact, since the launch of the OBOR (which later referred as the BRI) in 2013, the Malaysian government under Najib administration on one hand had generally shown very positive gestures in favor of strenghthening the collaborating with the PRC government in the context of BRI. On the other hand, there have also been negative and constant views within the public against the initiative, arguing that it would bring Malaysia into 'dependency' on China. BRI.

The following narrative explains further the contrasting Malaysian perspectives on the

On the perspective of Malaysia's support for the BRI, the former statement quoted from the former Prime Minister Najib can be considered as a vivid example. Another example is when Najib stated that the BRI "would derive massive benefits to Malaysia in terms of excellent infrastructure, connectivity, social facilities, better living standards and abundant business opportunities". ${ }^{31}$ From this statement it is obvious that the Malaysian government under Najib fully supported the BRI. The use of the words "massive" or "excellent" are more than adequate for explaining the government standing toward the offers from China through the BRI.

Following those supportive political expressions of the Najib administration toward the BRI, some Malaysian companies follow suit. Soon after the holding of the Belt and Road Forum in Beijing, on May 2017, the Malaysian companies together with their counterparts in China sealed nine memorandums of understandings (MOUs). The major projects included in those agreements are, among others, the Malaysia-China Kuantan Industrial Park, Melaka Gateway East Coast Rail Link, and Xiamen University Malaysia. ${ }^{32}$ (See Figure 5 and 6 as further references).

\footnotetext{
${ }^{29}$ Razak, Najib: “Why Malaysia Supports China’s Belt and Road”, South China Morning Post, 12 May 2017.

30 "Beijing-KL Relationship at Its Best Ever, says Xi Jinping”, The Straits Times, 14 May 2017.

${ }^{31}$ Lau, Rachel: “China's Belt and Road: What's in it for Malaysia”, Borneo Post Online, 3 September 2017.

${ }^{32}$ Lau, op. cit.
} 
Figure 5: BRI Investment and Infrastructure Projects in Malaysia

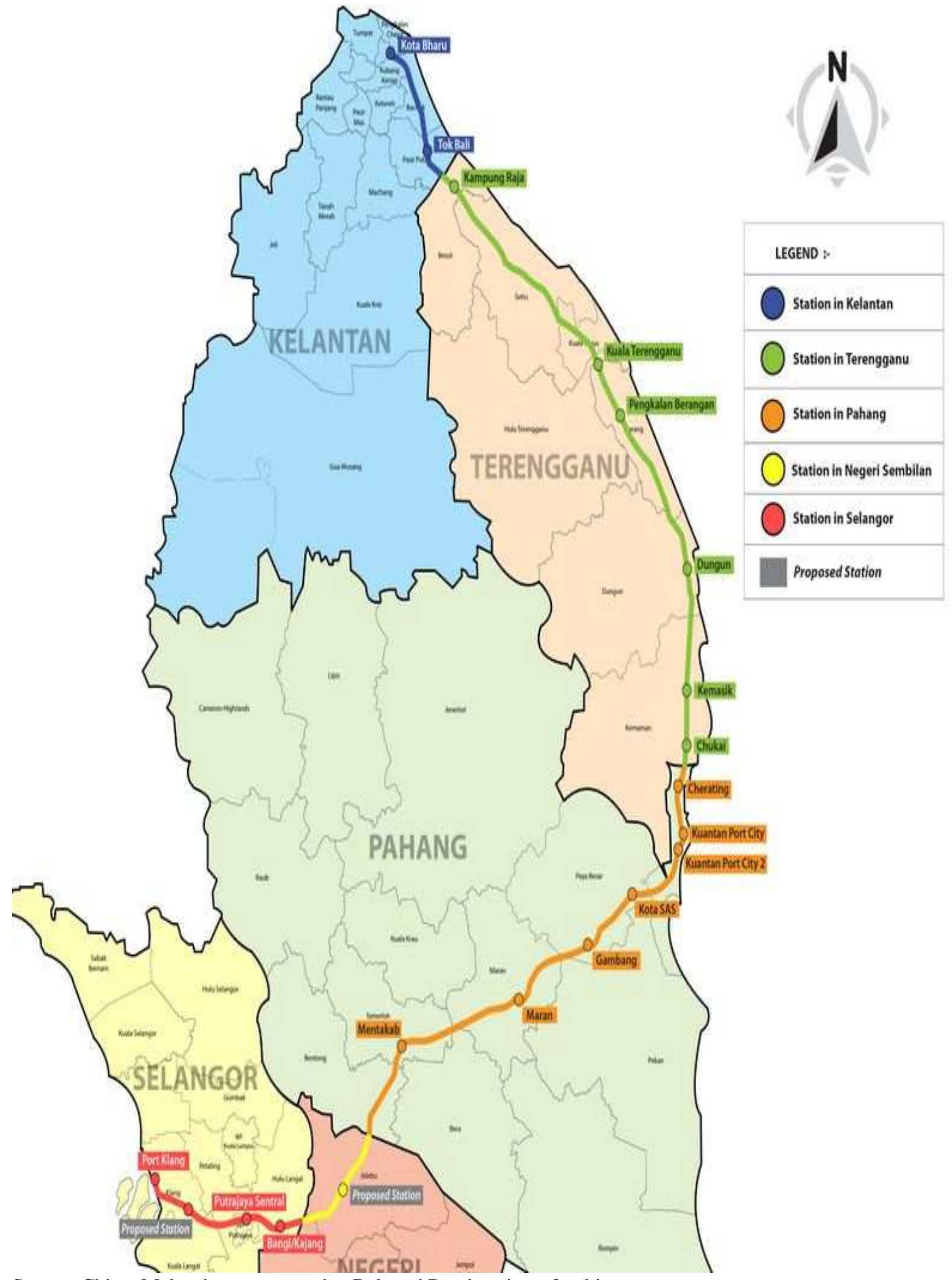

Source: China, Malaysia restart massive Belt and Road project after hiccups,

https://www.thestar.com.my/business/business-news/2019/07/25/china-malaysia-restart-massive-belt-and-roadproject-after-hiccups 
Figure 6: One Belt, One Road: with the Silk Road Initiatives by China; Mapping of ChinaMalaysia's Proposed MoU, Projects, \& Investments (as of 2016)

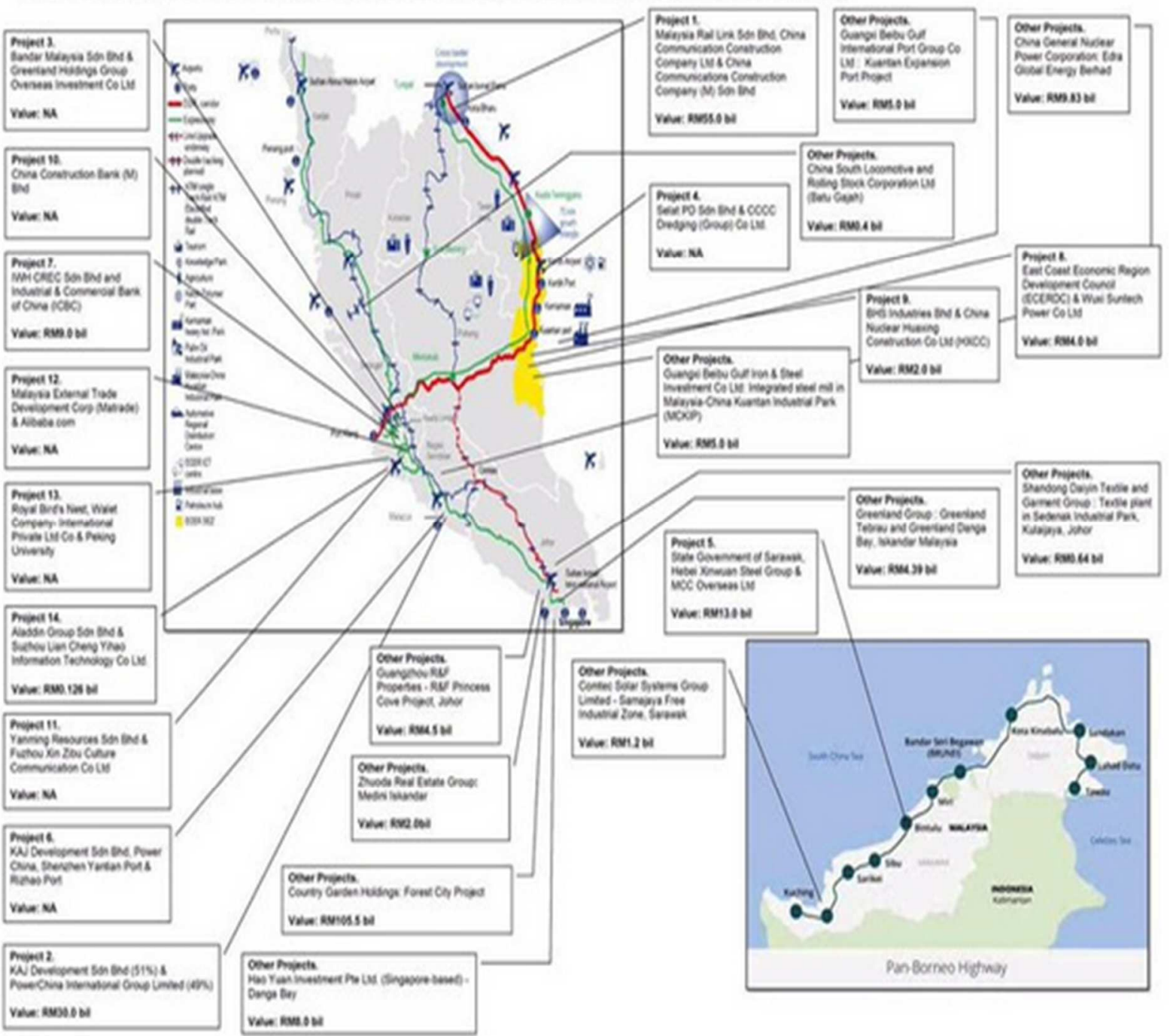

Source: The Chinafication of Malaysia, https://twitter.com/raishussin/status/823574036839952385

The Malaysian government under Prime Minister Najib moved further toward the BRI. In order to protect its interests in establishing collaboration with China, the government suggested that both sides had to provide a dispute settlement arrangement. Razak hoped that "the two countries could cooperate through the Kuala Lumpur Regional Center for Arbitration (KLRCA) and the China International Economic and Trade Arbitration Commission (CIETAC)" with a purpose of harmonizing arbitration law. ${ }^{33}$

Despite all these positive movements towards the BRI, there are strong critics coming from the Malaysian public. Among the strongest critics was former Malaysian Prime Minister Mahathir Mohammad who served his country from 1981 to 2003 (and later 2018-2020). Mahathir asserted that the strong inclination of Malaysia to China could erode Malaysia's sovereignty and could bring back the bad memories of Malaysia's long colonial rule under the United Kingdom. ${ }^{34}$ Later, when Mahathir succeeded PM Najib in May 2018, the government approach to BRI changed dramatically. Cheow-Bing writes, "After the change of government,

\footnotetext{
${ }^{33}$ Parameswaran, Prashanth: “China, Malaysia Mull Dipute Resolution for 'Belt and Road' Countries”, The Diplomat, 20 September 2016.

${ }^{34}$ Jaipragas, Bhavan:" Belt and Road Role for Malaysia, if It Overcomes Suspicions of China", South China Morning Post, 13 May 2017.
} 
the future of these projects immediately was put into question. Three projects were almost immediately suspended: ECRL, Trans-Sabah Gas Pipeline, and Multi-Purpose Pipeline." 35 (See Figure 7 for selected projects under Najib).

Figure 7: Selected China-related Infrastucture or Real Estate Projects in Malaysia under Najib

\begin{tabular}{|c|c|c|c|c|}
\hline Project & $\begin{array}{l}\text { Nature of the } \\
\text { Project }\end{array}$ & 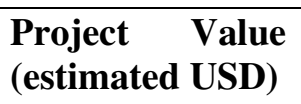 & $\begin{array}{l}\text { Major Chinese } \\
\text { Investor/Partner }\end{array}$ & Years \\
\hline Malacca Gateway & Port & 10 billion & $\begin{array}{l}\text { China Power } \\
\text { International }\end{array}$ & $2014-2025$ \\
\hline $\begin{array}{l}\text { MalaysiaChina } \\
\text { Kuantan } \\
\text { Industrial Park }\end{array}$ & Industrial Part & 806 million & $\begin{array}{l}\text { Guangxi Beibu } \\
\text { Gulf International } \\
\text { Port Group }\end{array}$ & $2013-2020$ \\
\hline $\begin{array}{ll}\text { Kuantan } & \text { Port's } \\
\text { Expansion (Deep } \\
\text { Water Terminal) }\end{array}$ & Port & 950 million & $\begin{array}{l}\text { Guangxi Beibu } \\
\text { Gulf International } \\
\text { Port Group }\end{array}$ & 2016-2039 \\
\hline $\begin{array}{ll}\text { Digital } & \text { Free } \\
\text { Trade Zone } & \end{array}$ & $\begin{array}{l}\text { Free trade zone, } \\
\text { logistics base }\end{array}$ & 100 million & Alibaba & 2016-?? \\
\hline Forest City & Real estate & 100 billion & Country Garden & 2013-2035 \\
\hline $\begin{array}{l}\text { Gemas-Johor } \\
\text { Bahru Electrified } \\
\text { DoubleTracking } \\
\text { Railway }\end{array}$ & Railway & 2 billion & $\begin{array}{l}\text { A consortium of } \\
\text { China Railway } \\
\text { Engineering } \\
\text { Corporation, } \\
\text { China Railway } \\
\text { Construction } \\
\text { Corporation, and } \\
\text { China } \\
\text { Communications } \\
\text { Construction } \\
\text { Corporation }\end{array}$ & $2016-2021$ \\
\hline $\begin{array}{l}\text { Trans-Sabah Gas } \\
\text { Pipeline }\end{array}$ & Pipeline & 1 billion & $\begin{array}{l}\text { China Petroleum } \\
\text { Pipeline Bureau }\end{array}$ & 2017-?? \\
\hline $\begin{array}{l}\text { Multi-Product } \\
\text { Pipeline }\end{array}$ & Pipeline & 1.35 billion & $\begin{array}{l}\text { China Petroleum } \\
\text { Pipeline Bureau }\end{array}$ & 2017-?? \\
\hline $\begin{array}{l}\text { East Coast Rail } \\
\text { Link }\end{array}$ & Rail & $\begin{array}{l}13 \text { billion, later } \\
\text { revised to } 20 \\
\text { billion }\end{array}$ & $\begin{array}{l}\text { China } \\
\text { Communications } \\
\text { Construction } \\
\text { Corporation }\end{array}$ & $2017-2024$ \\
\hline
\end{tabular}

Source: Chow-Bing, op. cit., p. 28.

Other criticisms were even tougher, more personal, against Najib Razak. One criticism argues that the embrace of Malaysia to the BRI is due to Najib's desperate survival strategy after the $1 \mathrm{MDB}$ scandal (an abbreviation of the 1Malaysia Development Berhard), that has put Najib as the most responsible person. ${ }^{36}$ Thus far the global investigations suggest that more than US\$ 1

\footnotetext{
${ }^{35}$ Chow-Bing, Ngeow (2019): "Malaysia-China Cooperation on the Belt and Road Initiative under the Pakatan Harapan Government: Changes, Continuities, and Prospects", in NISD ASEAN Workshop 2019” China's BRI and ASEAN". Tokyo, the National Institute for Defense Studies.

${ }^{36}$ Cheng-chwee, Kuik: “Will Malaysia Get Burned by Belt and Road?”, The Nation, 6 November 2017.
} 
billion entered Najib's personal bank accounts, and most of this amount came from the stateowned investment fund $1 \mathrm{MDB}$.

Another criticism against Najib Razak comes from a non-governmental organization namely Perkasa, an NGO focusing on the defense of Malay rights. The NGO has demanded the Najib government to come up with a white paper on the geopolitical implications of the BRI and this paper must be published and publicly discussed in relations to "Malaysia's labor, finance and security policies as well as the country's sovereignty". ${ }^{37}$ The NGO's Vice President stated,

If we study what's happening in Africa, Pakistan, Sri Lanka port projects, all these are Chinese investment. If we are able to study the weaknesses they had down there, by welcoming all these big projects from China, we are well prepared to handle them in order to avoid any future weaknesses or failures for that matter.

Last but not least, there is also a strong criticism that these scholars believe represents the grassroots sentiment about Chinese rule and increasing dominance. The criticism comes from Nurul Izzah Anwar, the vice president of the opposition Parti Keadilan Rakyat (People's Justice Party), of whom said that the investment from China to Malaysia are "too much, too fast, too soon". 38

As a consequence, when Najib Razak was toppled down as Prime Minister in 2018 and was replaced by Mahathir Mohammad (and later succeeded by Muhyiddin Yassin as of 1 March 2020), the close cooperation between Malaysia and China has shifted. In the context of BRI, Malaysia may continue its cooperation with China in the future. However, it would continue with reservations.

\section{Analytica Facts of Indonesians and Malaysians}

From the above narrative, it is obvious that there are mixed perceptions in Indonesia and Malaysia concerning the BRI. The two governments (Indonesia under Joko Widodo and Malaysia under Najib Razak) have shown their supports to the BRI. Nonetheless criticisms still exist particularly among the civil society.

For the Joko Widodo administration, the support it renders to the BRI is most probably due to its policy of developing infrastructure aggressively. As this policy requires huge amount of financial investment, the offers by the PRC through the BRI are viewed as one of the ways out in funding the already planned projects.

Nonetheless, the criticisms from the public are the facts that the Jokowi administration must face. Even further, beside the public acceptance as one of the important factors, the administration must pay attention to other important aspects particularly from the perspectives of international politics and economy.

As one of the countries crossed by the Belt and Road Initiative, Indonesia needs to keep a close watch on BRI. In international politics, Indonesia must always observe the dynamics of rivalry between the axis of US and China. It is obvious that during the administration of Joko Widodo since 2014, there have been tendencies that Indonesia keeps getting closer to China. On one hand this can be understood because of the strong interest of President Jokowi to build infrastructure on land and sea.

On the other hand, Jokowi administration still needs to be careful and not too inclined to China. Such an overwhelming attitude to the PRC could disrupt Indonesia's relations with

\footnotetext{
${ }^{37}$ Palansamy, Yiswaree: "Perkasa wants Putrajaya to come Clean on Foreign Investments", Malay Mail, 22 April 2017.

${ }^{38}$ Cheng-Chwee, op. cit.
} 
the critically important countries, especially the United States, Australia, Britain and the EU. The administration must bear in mind the classic proverb, which is often used as a reference in the world of diplomacy that says, "The friend of my enemy is my enemy." The good relations between Indonesia and those countries have been built long enough. Theoretically, it is not easy for a country to build rapport. Yet sometimes the relationship can go down drastically when disruptive problems arise.

As one of suggested ways forward, the principle of 'free and active' foreign policy which has been the guidance of Indonesia needs to continue as a reference. The tendency towards one axis, either to the US or China, will potentially negatively affect the dynamics of Indonesia's foreign policy not only bilaterally but also regionally and multilaterally. The neutral attitude is expected to be able to keep Indonesia with various interests.

Economically, Indonesia's participation with the BRI may offer a positive option. Especially if this is associated with the Joko Widodo government's policies that are aggressively building infrastructure. Policies on toll roads, railway construction, and many other have been substantially securing injections of funds from the PRC government.

Nevertheless, Indonesia still needs to be particularly cautious about the 'debt trap'. A number of prominent Indonesian economists have given warning on the possibility of mangkrak (stalled) of a number of high-profile infrastructure projects due to the lacks of funds in the country. A prominent economist Faisal Basri, for example, had predicted that the mega development Train projects (Light Rail Train) would be stalled. ${ }^{39}$ For that he suggested that infrastructure projects should be rescheduled. ${ }^{40}$ In fact, at the time of writing of this article, his prediction is proven that the project is now stalled. The main reason is due to disturbances the project has caused in the busy toll roads of Jakarta-Cikampek and Purbaleunyi routes, combined with the environmental and human concerns. ${ }^{41}$ One thing that the administration must pay attention to is that if the situation is uncontrollable, as noted earlier, it would force Indonesia into a 'debt trap' and make this country to be overdependent toward China'.

In terms of public acceptance, the involvement of Indonesia with the BRI needs to prioritize the dimension of public diplomacy. In other words, both the governments of Indonesia and China should be able to keep the public sentiment of Indonesia to the BRI not to be seen as one form of penetration of Chinese values into the country.

The rise of anti-communist sentiment, as seen in the the recent heated public debate on the failed 30 September 1965 Indonesian Communist Party coup d'état (G30S PKI), is a strong indication of the public's resistance to the resurgence of communism in Indonesia. If this phenomenon is not managed carefully then it is feared it will strengthen the negative sentiment of the Indonesian public, both to the government of the PRC and to the government of Indonesia.

In the case of Malaysia, this country has even experienced a more troublesome situation, that led to the fall of Najib Razak as prime minister. Even though his fall was not necessarily linked to his policy with the BRI, it was clear that his successor, prime minister Mahathir Mohamad, used it as one example of the power misuse by Razak when leading Malaysia.

Najib's strong inclination toward the BRI allows to present three possible hypotheses: first, the administration had genuine and high expectations on China and its intention to assist the country in building its ambitious infrastructure projects; second, as previously indicated,

\footnotetext{
${ }^{39}$ Suryowati, Estu: "Faisal Basri: Proyek LRT Jabodebek Diprediksi Mangkrak”, Kompas, 8 Maret 2017.

${ }^{40}$ Sinaga, Mesti:” Faisal Basri: Tak Ada Jalan Lain, Reschedule Infrastruktur”, Kontan, 6 October 2017.

${ }^{41}$ The Jakarta Post: "SOE Ministry Demands Assessment of Halted High-Speed Railway Project", the Jakarta Post, 2 March 2020.
} 
the close cooperation was used to divert public attention on the 1MDB scandal; and three, the funds dispensed by China under the BRI were to be used for personal or party's interests, a clear case of corruption.

From the above three assumptions, Malaysians did not really buy the first one. In fact, Malaysians were more inclined to the second and third assumptions, both being voiced by the political elites (particularly from the opposition parties) and NGOs. It was tested by the winning opposition parties (through a coalition namely Pakatan Harapan) toppling down Najib Razak as prime minister in 2018. Despite that the main issue used to topple Najib was the 1MDB scandal, it is also important to note that the issue of Malaysia's strong inclination toward the BRI was also brought up by Najib's strong critics, including Mahathir Mohammad who later succeeded him as Malaysia's prime minister.

\section{Conclusion}

Since the launching of China's One Belt and One Road (OBOR) in 2013, later renamed as Belt and Road Initiative (BRI) in 2017, this policy has triggered much discussions and debate, with pros and cons. The iniciative for connecting 68 countries in Asia, Europe, and Africa, has received various comments, ranging from highly supportive to very negative statements. Indonesia and Malaysia are no exception.

The views of the Indonesian government under the Joko Widodo administration (20142019 and 2019-2024) in general support he BRI. Yet public acceptance suggests something different. In general, public do not really welcome a strong tilt toward China. Even more, the public view China more as a threat rather than a friendly country that can bring great advantages to Indonesians in general.

A similar situation also occurred in Malaysia under the Najib Razak administration (2009-2018). It is very obvious that Najib tried to implement a Chinese-oriented policy. But the Malaysian public was of different opinion. Later Najib was toppled down as prime minister. Chief among the issues for his fall was his 1MDB corruption scandal. The opposition parties and the NGOs also used the issue of Najib's close inclination to China as one of their crucial critics.

This narrative suggests that the governments of both countries and other countries who have shown a strong commitment to the BRI, have to pay close attention to the perceptions of their people. Unlike China, where public aspirations are heavily controlled, public perceptions in democratic countries, like Indonesia and Malaysia, play a role and its oblivion can be the catalyst for political catastrophes. 


\section{Bibliography}

Aco, Hasanudin: "Survei Median: China Dianggap Sebagai Ancaman Terbesar Bagi Indonesia", Tribunnews, 16 November 2017.

"Beijing-KL Relationship at Its Best Ever, says Xi Jinping”, The Straits Times, 14 May 2017.

Bennon, Michael (2019): "Bailing Out China's Belt and Road", Center for Strategic and International Studies.

Cai, Peter (2017): Understanding China's Belt and Road Initiative. Sydney: Lowy Institute for International Policy.

Center for Strategic and International Studies (2017): “Ada Apa dengan Milenial? Orientasi Sosial, Ekonomi, dan Politik “, CSIS.

Chellaney, Brahma (2017): “China's Debt-Trap Diplomacy”, in Project Syndicate.

Cheng-chwee, Kuik: “Will Malaysia Get Burned by Belt and Road?", The Nation, 6 November 2017.

Coordinating Ministry of Maritime Affairs, Republic of Indonesia (2019): “A Synergy between Two Great Nations: China's Belt \& Road Initiative and Indonesia's Global Maritime Fulcrum”, Republic of Indonesia.

Coordinating Ministry of Maritime Affairs, Republic of Indonesia (2018): "Beberapa Kerja Sama Indonesia-Tiongkok Ditandatangani, Menko Luhut: Kami Tidak Ingin Hanya Bicara “, Republic of Indonesia.

Cruz, Elfren S.: “China Debt Trap”, in The Philippine Star, 3 August 2017.

Damuri, Yose Rizal; Perkasa, Vidhyandika; Atje, Raymond and Hirawan, Fajar (2019): Perceptions and Readiness of Indonesia towards the Belt and Road Initiative: Understanding Local Perspectives, Capacity, and Governance. Jakarta, Center for Strategic and International Studies.

Gerstel, Dylan: "It's a (Debt) Trap! Managing China-IMF Cooperation Across the Belt and Road", New Perspestives in Foreign Policy, Issue 16, Center for Strategic \& International Studies (17 October 2018).

Haenle, Paul; Trenin, Dmitri; Baguev, Alexander; Valasek, Tomas; Baruah, Dashana M.; Yujun, Feng and Bin, Ma (2019): "How are various Countries Responding to China's Belt and Road Initiative? “, in Carnegie-Tsinghua Center for Global Policy.

Hurley, John; Morris, Scott and Portelance, Gailyn (2018): "Examining the Debt Implication of the Belt and Road Initiative from a Policy Perspective" in CGD Policy Paper 121. Washington, Center for Global Development.

Jaipragas, Bhavan: "Belt and Road Role for Malaysia, if It Overcomes Suspicions of China", South China Morning Post, 13 May 2017.

Lau, Rachel: "China's Belt and Road: What's in it for Malaysia", Borneo Post Online, 3 September 2017.

Parameswaran, Prashanth: "China, Malaysia Mull Dipute Resolution for 'Belt and Road' Countries", The Diplomat, 20 September 2016.

Palansamy, Yiswaree: "Perkasa wants Putrajaya to come Clean on Foreign Investments", Malay Mail, 22 April 2017. 
Sheany: "Jokowi Optimistice about China's Belt and Road Initiative", Jakarta Globe, 16 May 2017.

Shambaugh, David (2014): China at the Crossroads: Ten Major Reform Challenges. Washington: the Brookings Institution.

Silver, Laura; Devlin, Kat and Huang, Christine (2019): "China's Economic Growth Mostly Welcomed in Emerging Markets, but Neighbors Wary of Its Influence", Pew Research Center.

Suryowati, Estu: "Faisal Basri: Proyek LRT Jabodebek Diprediksi Mangkrak", Kompas, 8 Maret 2017.

The Jakarta Post: "SOE Ministry Demands Assessment of Halted High-Speed Railway Project”, the Jakarta Post, 2 March 2020.

Yamada, Go (2018): "Is China's Belt and Road Working? A Progresss Report from Eight Countries", in Nikkei Asian Review, 28 March 2018. 